\title{
Inventory of managed honey bee population in Zhytomyr region (Ukraine)
}

\author{
O. V. Lisohurska, D. V. Lisohurska, V. M. Sokolyuk ${ }^{*}$, S. V. Furman, M. M. Kryvyi, \\ I. P. Ligomina
}

\author{
Zhytomyr National Agroecological University, 7, Stary Blvd, Zhytomyr, 10008, Ukraine \\ *Corresponding author E-mail: vmsokoluk@gmail.com
}

Received: 15.01.2019. Accepted 15.02.2020

\begin{abstract}
Over the last decades, the number of honey bee colonies in the world has been declining. A honey bee is the most important pollinator in agriculture. According to estimates, such a situation can threaten the food security of humanity. The purpose was to investigate the specific aspects of the managed honey bee population in Zhytomyr region. The population dynamics, number, and density were determined. For this purpose the statistics of the State Statistics Committee of Ukraine on the number of bee colonies by categories of producers in Ukraine and Zhytomyr region were used. It was established that in Zhytomyr region over the past quarter century, the population of honey bee (Apis mellifera L.) has increased by 2 times up to 193.4 thousand colonies. During the same period, the number of bee colonies in Ukraine has increased by 1.4 times. At present, Zhytomyr region is a leader in the state in the development of the beekeeping industry. Eight percent of all honey bee colonies in the country are concentrated here. In the Zhytomyr region, the density of honey bee population is one of the highest in Ukraine. 82 colonies are concentrated here on one conditional pasture area (1256 hectares), with 7 colonies per 100 hectares of land. In Ukraine, these indicators are 52 and 4 respectively. The distribution of bee colonies in the region is uneven. The vast majority of colonies (58.5\%) are concentrated in the Polissia. There are from 1 to 18 colonies per 100 hectares of land in each of the units in the region, on the conditional pasture area from 16 to 224. The results of these studies are relevant for the commodity apiaries for the rational use of honey flow and to make a well-considered decision on the prospect of increasing the number of bee colonies. Further work will be aimed at the investigation into the melliferous base and the calculation of the feed balance of the beekeeping industry in Zhytomyr region.
\end{abstract}

Key words: Honey bee; Apis mellifera L; Bee colonies; Bee keeping

\section{Introduction}

The productivity of bee colonies depends to a large extent on the influence of exogenous factors. The most important ones include: the presence of a honey-bearing base, climatic conditions, temperature of the environment, etc. It significantly affects the growth of colonies and the stability of the microclimate in the nest (Vishchur et al., 2016; Faly et al., 2017; Shulman et al., 2017; Kovalskyi et al., 2018; Kovalchuk et al., 2019; Vishchur et al., 2019).

Beekeeping has been declining in Europe and the United States in recent decades, as evidenced by the reduction in the number of honey bee colonies (Apis mellifera L.) (Ellis et al., 2010; Potts et al., 2010). According to Neumann \& Carreck (2010), these losses are approximately $30 \%$ in the United States, $1.8-53 \%$ in Europe, $25 \%$ in Japan, and $10-85 \%$ in Central Asia. Scientists identify a number of reasons for the possible causes for dying of bee colonies, including cell phones, genetically modified organisms and nanotechnology, which may have overshadowed much more likely explanations such as pests and diseases, pesticides, fodder base and beekeeping technologies.

Dahle (2010) investigated that regions where varroa mites are widespread (USA, Europe, Central Asia, Japan) tend to suffer heavier losses than those where these mites are absent (Australia, South America, and Africa). However, he emphasizes that the mite alone does not explain all the recent losses. According to Kulhanek et al. (2017), the loss of bee colonies in the summer (23.6\%) approaches the loss after wintering (26.9\%), which is particularly worrying. Studies by Potts et al. (2010) in 18 European countries found a decrease in colonies in Central European countries and a slight increase in the Mediterranean ones. The authors associate these results with the decrease in the number of beekeepers. Among the causes for dying of honey bee colonies, Neumann \& Carreck (2010) name viruses (Berthoud et al., 2010; Carreck et al., 2010a, b; Martin et al., 2010), nosematosis (Paxton, 2010; Santrac et al., 2010), varroatosis (Carreck et al., 2010b; Dahle, 2010; Martin et al., 2010), pesticides and acaricides (Chauzat et al., 2010b; Medrzycki et al., 2010; Harz et al., 2010), reduction in genetic diversity (Meixner et al., 2010) and loss of habitats (Potts et al., 2010). According to Genersch E. et al (2010), honey bee is the most important pollinator in agriculture providing over $90 \%$ of commercial pollination services. According to current estimates, the global demand for it will continue to grow. As a consequence, the persistent decline in the number of bee colonies in North America and Europe, which has been observed for years, poses a serious threat to agriculture. This is testifies the urgent need to study the honey bee populations in different regions, as well as the factors that affect their decline. Therefore, we had a purpose to investigate the density and abundance of the managed honey bee population in Zhytomyr region (Ukraine).

\section{Material and Methods}

The object of our study was a honey bee (Apis mellifera L.), whereas the subject was a honey bee population in the Zhytomyr region. Research task was to determine by the conventional methods (Brovarskyj et al., 2017) and to analyze the number, dynamics and density of managed honey bee population in Zhytomyr region. The research area were two soil and climatic zones, the Forest steppe and Polissia regions. We also collected data in certain aministrative units and compare our results with other Ukrainian 
regions. The number was determined by calculating the total number of bee colonies located at agricultural enterprises and personal subsidiary plots in the administrative units of Zhytomyr region (in 2013-2017) and regions of Ukraine (in 1992-2017). The population dynamics was analyzed for twenty-five years (1992-2017. The density was calculated per 100 and 1256 ha (conditional pasture area). The official data of the State Statistics Committee of Ukraine on the number of bee colonies in Ukraine by regions (1992-2017) and in Zhytomyr region by administrative units (2013-2017) were also used in our study. The statistical processing of data was performed using a Microsoft Office Excel software.

\section{Results and Discussion}

It was discovered that the honey bee population in Zhytomyr region has doubled over a quarter century - from 90.0 to 195.6 thousand colonies (Table 1).

Table 1. Size of managed honey bee population in Zhytomyr region, thousand colonies.

\begin{tabular}{|c|c|c|c|c|}
\hline \multirow{2}{*}{ Year } & \multicolumn{3}{|c|}{ Category of households } & \multirow{2}{*}{$\begin{array}{l}\text { Share of bee colonies from } \\
\text { total in Ukraine, } \%\end{array}$} \\
\hline & Agricultural & $\begin{array}{l}\text { personal subsidiary } \\
\text { plots of population }\end{array}$ & Total & \\
\hline 1992 & 43.7 & 46.3 & 90.0 & 3 \\
\hline 1993 & 40.7 & 125.5 & 166.2 & 4 \\
\hline 1994 & 36.0 & 133.3 & 169.3 & 4 \\
\hline 1995 & 32.8 & 134.4 & 167.2 & 4 \\
\hline 1996 & 28.5 & 111.0 & 139.5 & 4 \\
\hline 1997 & 23.6 & 94.4 & 118.0 & 4 \\
\hline 1998 & 23.3 & 94.8 & 118.1 & 4 \\
\hline 1999 & 21.5 & 80.2 & 101.7 & 3 \\
\hline 2000 & 18.9 & 76.9 & 95.8 & 3 \\
\hline 2001 & 16.2 & 72.3 & 88.5 & 3 \\
\hline 2002 & 16.0 & 82.8 & 98.8 & 3 \\
\hline 2003 & 15.1 & 85.5 & 100.6 & 4 \\
\hline 2004 & 10.2 & 87.0 & 97.2 & 4 \\
\hline 2005 & 8.7 & 120.2 & 128.9 & 4 \\
\hline 2006 & 8.7 & 149.9 & 158.6 & 5 \\
\hline 2007 & 7.8 & 149.8 & 157.6 & 5 \\
\hline 2008 & 6.5 & 150.1 & 156.6 & 5 \\
\hline 2009 & 4.7 & 152.3 & 157.0 & 5 \\
\hline 2010 & 4.3 & 151.1 & 155.4 & 5 \\
\hline 2011 & 3.9 & 152.1 & 156.0 & 5 \\
\hline 2012 & 2.9 & 156.2 & 159.1 & 6 \\
\hline 2013 & 3.0 & 174.9 & 177.9 & 6 \\
\hline 2014 & 2.6 & 188.6 & 191.2 & 6 \\
\hline 2015 & 2.7 & 190.7 & 193.4 & 7 \\
\hline 2016 & 2.4 & 191.6 & 194.0 & 7 \\
\hline 2017 & 2.2 & 193.4 & 195.6 & 8 \\
\hline
\end{tabular}

This growth was due to personal subsidiary plots, where the number of bee colonies increased fourfold. However, the dynamics at agricultural enterprises is exactly the opposite. In this category of households the number of colonies decreased by 20 times - from 43.7 to 2.2 thousand. During the period under study, there were several waves of fluctuation in the honey bee population in Zhytomyr region. The first occurred in 1993. That year the number of colonies increased to 166.2 thousand, i.e., by 1.8 times.

A sharp decline in the number of colonies occurred between 1996 and 1997 . A gradual decrease in the number of bee colonies was observed until 2004. In general, during this period the number of honey bee population decreased to 97.2 thousand colonies.

The next wave of growth occurred in 2005-2006. During that time, the number of colonies increased to 158.6 thousand and remained almost stable for seven consecutive years until 2012.

The last wave of growth was observed in 2013-2017. In 2013, the number of bee colonies increased by 18.8 thousand, in 2014 by another 13.3 thousand. In the last three years there was an increase of $0.6-2.2$ thousand colonies every year.

What's interesting is thatin the last twenty-five years honey bee population in Ukraine has decreased from 3525.7 to 2487.1 thousand colonies, i.e., by 1.4 times.

At present, $8 \%$ of all honey bee colonies in Ukraine are concentrated in Zhytomyr region (Table 2). This indicator had risen by 2.7 times from 1992 to 2017 . This share is $6-7 \%$ in the Khmelnytskyi, Vinnytsia, Donetsk, Mykolaiv, Ivano-Frankivsk and Poltava regions, in the other regions it amounts to $1-5 \%$. 
Table 2. Size of managed honey bee population in administrative units, soil and climatic zones of Zhytomyr region, thousand colonies.

\begin{tabular}{|c|c|c|c|c|c|c|}
\hline \multirow{2}{*}{ Unit, soil and climatic zone } & \multicolumn{4}{|c|}{ Year } & \multirow{2}{*}{ Mean } & \multirow{2}{*}{$\begin{array}{l}\text { Share of bee } \\
\text { colonies, \% }\end{array}$} \\
\hline & 2014 & 2015 & 2016 & 2017 & & \\
\hline Andrushivka & 7.2 & 6.6 & 6.6 & 6.7 & 6.8 & 3.5 \\
\hline Baranivka & 5.0 & 5.5 & 5.6 & 5.8 & 5.5 & 2.8 \\
\hline Berdychiv & 12.3 & 12.1 & 12.1 & 12.4 & 12.2 & 6.3 \\
\hline Brusyliv & 4.0 & 4.7 & 4.8 & 4.7 & 4.6 & 2.4 \\
\hline Zhytomyr & 10.5 & 10.7 & 10.8 & 10.9 & 10.7 & 5.5 \\
\hline Korostyshiv & 4.4 & 4.0 & 4.1 & 4.2 & 4.2 & 2.2 \\
\hline Liubar & 10.8 & 9.8 & 9.8 & 9.8 & 10.1 & 5.2 \\
\hline Novohrad-Volynskyi & 9.7 & 10.2 & 10.2 & 10.2 & 10.1 & 5.2 \\
\hline Popilnia & 9.5 & 10.1 & 10.2 & 10.2 & 10.0 & 5.2 \\
\hline Radomyshl & 4.2 & 4.9 & 4.6 & 4.6 & 4.6 & 2.4 \\
\hline Romaniv & 7.5 & 7.4 & 7.4 & 7.6 & 7.5 & 3.9 \\
\hline Ruzhyn & 17.5 & 17.6 & 17.7 & 17.9 & 17.7 & 9.1 \\
\hline Chudniv & 10.0 & 9.3 & 9.3 & 9.2 & 9.5 & 4.9 \\
\hline Forest steppe & 112.6 & 112.9 & 113.2 & 114.2 & 113.2 & 58.5 \\
\hline Yemilchyno & 9.8 & 10.6 & 10.6 & 10.4 & 10.4 & 5.4 \\
\hline Korosten & 9.9 & 10.5 & 10.6 & 10.6 & 10.4 & 5.4 \\
\hline Luhyny & 5.2 & 4.4 & 4.4 & 4,3 & 4.6 & 2.4 \\
\hline Malyn & 7.1 & 7.1 & 7.1 & 7.1 & 7.1 & 3.7 \\
\hline Narodychi & 4.2 & 4.1 & 4.1 & 4.2 & 4.2 & 2.2 \\
\hline Ovruch & 19.5 & 19.1 & 19.2 & 19.4 & 19.3 & 10.0 \\
\hline Olevsk & 4.0 & 3.9 & 4.0 & 4.2 & 4.0 & 2.1 \\
\hline Pulyno & 6.9 & 7.7 & 7.7 & 7.9 & 7.6 & 3.9 \\
\hline Khoroshiv & 5.5 & 5.9 & 5.9 & 6.0 & 5.8 & 3.0 \\
\hline Cherniakhiv & 6.5 & 7.2 & 7.2 & 7.3 & 7.1 & 3.7 \\
\hline Polissia & 78.6 & 80.5 & 80.8 & 81.4 & 80.3 & 41.5 \\
\hline
\end{tabular}

Analysis of specific aspects of the distribution of honey bee population in Zhytomyr region between soil and climatic zones showed that there are by 1.4 times more colonies in the Polissia than in the Forest steppe. $58.5 \%$ of bee colonies of the region are located here. In these regions there has been a gradual increase in the size of their population over the last four years. In the Polissia units, the number of bee colonies increased by 1.6 thousand, in Forest steppe by 2.8 thousand. The largest share of honey bee colonies is concentrated in two administrative units - Ruzhyn, which is located in the Forest steppe, and Ovruch in the Polissia. This indicator is 9.1 and 10, respectively. Eight administrative units have between 2.1 and $3 \%$ of bee colonies of the region, the other thirteen from 3.5 to 6.3. In Zhytomyr region, the density of honey bee was seven colonies per 100 ha, while it was 82 colonies per one conditional pasture area (1256 ha, Table 3).

Table 3. Density of honey bee population in Zhytomyr region.

\begin{tabular}{lll}
\hline \multicolumn{1}{c}{ Unit, soil and climatic zone } & per $\mathbf{1 0 0}$ ha & Density of bee colonies \\
Andrushivka & 7 & per $\mathbf{1 2 5 6}$ ha \\
Baranivka & 6 & 88 \\
Berdychiv & 14 & 73 \\
Brusyliv & 8 & 173 \\
Zhytomyr & 5 & 94 \\
Korostyshiv & 2 & 63 \\
Liubar & 10 & 30 \\
Novohrad-Volynskyi & 8 & 124 \\
Popilnia & 5 & 98 \\
Radomyshl & 4 & 57 \\
Romaniv & 8 & 45 \\
Ruzhyn & 18 & 103 \\
Chudniv & 9 & 224 \\
Forest steppe & $\mathbf{7}$ & 111 \\
Yemilchyno & 12 & $\mathbf{8 9}$ \\
Korosten & 7 & 150 \\
Luhyny & 4 & 90 \\
Malyn & 9 & 55 \\
\hline
\end{tabular}




\begin{tabular}{lll} 
Narodychi & 3 & 36 \\
Ovruch & 9 & 116 \\
Olevsk & 1 & 16 \\
Pulyno & 8 & 96 \\
Khoroshiv & 7 & 88 \\
Cherniakhiv & 9 & 108 \\
Polissia & $\mathbf{6}$ & $\mathbf{7 5}$ \\
\hline
\end{tabular}

The highest density of bee colonies is in the Ruzhyn administrative unit which is located in the Forest steppe. There are 18 colonies per 100 hectares and 224 per one conditional pasture area. This is twice as much as in the average unit of Zhytomyr region. In another two Forest steppe administrative units (Berdychiv and Liubar) and one Polissia administrative unit (Yemilchyno) these indicators are not less than 10 and 125, respectively. Three administrative units of the Forest steppe (Novohrad-Volynskyi, Romaniv and Brusyliv) and four administrative units of the Polissia (Ovruch, Cherniakhiv, Malyn and Pulyno) are characterized by about the same density of bee colonies as the average in Zhytomyr region. In another four Forest steppe administrative units (Andrushivka, Baranivka, Zhytomyr and Popilnia) and two Polissia administrative units (Korosten and Khoroshiv), their number was not less than five per 100 ha and not less then 57 per one conditional pasture area. These values were 4 and 52 respectively regards average meaning in Ukraine. In Vinnytsia, Mykolaiv, Khmelnitskyi, Ivano-Frankivsk and Chernivtsi, the density of bee colonies was 8-10 colonies per 100 hectares; in the other regions it was $1-4$. In the former regions the density was $85-131$ colonies per one conditional pasture area and this was 15-69 colonies in the latter regions.

The lowest honey bee population density was registered in two administrative units of the Forest steppe (Radomyshl and Korosten) and three regions of the Polissia (Luhyny, Narodychi, and Olevsk) amounting to 1-4 and 16-55, respectively. The lowest density of bee colonies per unit area was observed in Olevsk region (Polissia) - 1 and 16, respectively.

\section{Conclusion}

During last twenty-five years (1992-2017), the size of honey bee colonies in Zhytomyr region has doubled and now amounts to 193.4 thousand. This region is one of the best in the country in the development of the beekeeping industry. Eight percent of all bee colonies in Ukraine are concentrated here, and the density of managed honey bee population is one of the highest in the country. There are 7 colonies per 100 hectares and 82 colonies per one conditional pasture area (1256 hectares). The distribution of bee colonies in Zhytomyr region is uneven towards soil and climatic zones and administrative units. The largest number of colonies was in Polissia (58.5\%). In some regions, there are 16-224 colonies per conditional pasture area and 1-18 colonies per 100 ha. Further work will be aimed at the investigation of melliferous base and the calculation of feed balance of the beekeeping industry in Zhytomyr region.

\section{References}

Berthoud, H. (2010). Virus infections and winter losses of honey bee colonies (Apis mellifera). Journal of Apicultural Research, 49(1), 60-65. doi: 10.3896/IBRA.1.49.1.08.

Brovarskyj, V. D. (2017). Metodyka doslidnoyi spravy u bdzhilnycztvi [Methodology of a test case in beekeeping]: navch. posib. Kyiiv: Publishing House "Vinnichenko" (in Ukrainian).

Carreck, N. L., Ball, B. V., \& Martin, S. J. (2010a). The epidemiology of cloudy wing virus infections in honey bee colonies in the UK. Journal of Apicultural Research, 49(1), 66-71. doi: 10.3896/IBRA.1.49.1.09.

Carreck, N. L., Ball, B. V., \& Martin, S. J. (2010b). Honey bee colony collapse and changes in viral prevalence associated with Varroa destructor. Journal of Apicultural Research, 49(1), 93-94. doi: 10.3896/IBRA.1.49.1.13.

Chauzat, M.-P. (2010). A case report of a honey bee colony poisoning incident in France. Journal of Apicultural Research, 49(1), 113-115. doi: 10.3896/IBRA.1.49.1.22.

Dahle, B. (2010). The role of Varroa destructor for honey bee colony losses in Norway. Journal of Apicultural Research, 49(1), 124125. doi: 10.3896/IBRA.1.49.1.26.

Ellis, J. D., Evans, J. D., \& Pettis, J. S. (2010). Colony losses, managed colony population decline and Colony Collapse Disorder in the United States. Journal of Apicultural Research, 49(1), 134-136. doi: 10.3896/IBRA.1.49.1.30.

Faly, L. I., Kolombar, T. M., Prokopenko, E. V., Pakhomov, O. Y., \& Brygadyrenko, V. V. (2017). Structure of litter macrofauna communities in poplar plantations in an urban ecosystem in Ukraine. Biosystems Diversity, 25(1), 29-38. doi: 10.15421/011705

Genersch, E. (2010). The German bee monitoring project: a long term study to understand periodically high winter losses of honey bee colonies. Apidologie, 41(3), 332-352. doi: 10.1051/apido/2010014.

Kovalchuk, I., Dvylyuk, I., Lecyk, Y., Dvylyuk, I., \& Gutyj, B. (2019). Physiological relationship between content of certain microelements in the tissues of different anatomic sections of the organism of honey bees exposed to citrates of argentum and cuprum. Regulatory Mechanisms in Biosystems, 10(2), 177-181. doi: 10.15421/021926

Kovalskyi, Yu., Gucol, A., Gutyj, B., Sobolev, O., Kovalska, L., \& Mironovych, A. (2018). Features of histolism and hystogenesis in the vital temperature range in the organism of honey bee (Apis mellifera L.) in the postembrional period. Ukrainian Journal of Ecology, 8(2), 301-307. doi: 10.15421/2018_342

Kulhanek, K. (2017). A national survey of managed honey bee 2015-2016 annual colony losses in the USA. Journal of Apicultural Research, 56(4), 328-340. doi: 10.1080/00218839.2017.1344496.

Martin, S. J., Ball, B. V., \& Carreck, N. L. (2010). Prevalence and persistence of deformed wing virus (DWV) in untreated or acaricidetreated Varroa destructor infested honey bee (Apis mellifera) colonies. Journal of Apicultural Research, 49(1), 72-79. doi: 10.3896/IBRA.1.49.1.10.

Medrzycki, P. (2010). Influence of brood rearing temperature on honey bee development and susceptibility to poisoning by pesticides. Journal of Apicultural Research, 49(1), 52-59. doi: 10.3896/IBRA.1.49.1.07.

Meixner, M. D. (2010). Conserving diversity and vitality for honey bee breeding. Journal of Apicultural Research. 49 (1): $85-92$. doi: $10.3896 /$ IBRA.1.49.1.12.

Neumann, P. N., \& Carreck, N. L. (2010). Honey bee colony losses. Journal of Apicultural Research, 49(1), 1-6. doi: $10.3896 /$ IBRA.1.49.1.01. 
Paxton, R. J. (2010). Does infection by Nosema ceranae cause «Colony Collapse Disorder» in honey bees (Apis mellifera)? Journal of Apicultural Research, 49(1), 80-84. doi: 10.3896/IBRA.1.49.1.11.

Potts, S. G. (2010). Declines of managed honey bees and beekeepers in Europe. Journal of Apicultural Research, 49(1), 15-22. doi: 10.3896/IBRA.1.49.1.02.

Santrac, V, Granato, A., \& Mutinelli, F. (2010). Detection of Nosema ceranae in Apis mellifera from Bosnia and Herzegovina. Journal of Apicultural Research, 49(1), 100-101. doi: 10.3896/IBRA.1.49.1.16.

Shulman, M. V., Pakhomov, O. Y., \& Brygadyrenko, V. V. (2017). Effect of lead and cadmium ions upon the pupariation and morphological changes in Calliphora vicina (Diptera, Calliphoridae). Folia Oecologica, 44(1), 28-37. doi: 10.1515/foecol-2017-0004 Vishchur, V. Y. Saranchuk, I. I., \& Gutyj, B. V. (2016). Fatty acid content of honeycombs depending on the level of technogenic loading on the environment. Visnyk of Dnipropetrovsk University. Biology, ecology, 24(1), 182-187. doi: 10.15421/011622

Vishchur, V. Y., Gutyj, B. V., Nischemenko, N. P., Kushnir, I. M., Salata, V. Z., Tarasenko, L. O., Khimych, M. S., Kushnir, V. I., Kalyn, B. M., Magrelo, N. V., Boiko, P. K., Kolotnytskyy, V. A., Velesyk, T., Pundyak, T. O., \& Gubash, O. P. (2019). Effect of industry on the content of fatty acids in the tissues of the honey-bee head. Ukrainian Journal of Ecology, 9(3), 174-179, doi: 10.15421/2019_727

\section{Citation:}

Lisohurska, O.V., Lisohurska, D.V., Sokolyuk, V.M., Furman, S.V., Kryvyi, M.M., Ligomina, I.P. (2019). Inventory of managed honey bee population in Zhytomyr region (Ukraine). Ukrainian Journal of Ecology, 10(1), 133-137. 